\title{
The Nutrition of Nigerian Peasants, with Special Reference to the Effects of Deficiencies of the Vitamin B Complex, Vitamin A and Animal Protein
}

\author{
By B. M. NICOL \\ Colonial Medical Service, Nigeria, and the Government Hospital, \\ Warri, Nigeria \\ (Received 21 March 1951)
}

Much of the present knowledge relating to the specific effects of deficiencies of single nutrients has been derived from relatively short-term experiments upon animals or human beings. The longer human experiments, e.g. those of Ancel Keys and his coworkers (Keys, Henschel, Taylor, Mickelsen \& Brozek, 1945) into the results of deficiency of vitamins of the B complex, of Crandon, Lund \& Dill (1940) into the effects of ascorbic-acid deficiency, or those of the Medical Research Council (Hume \& Krebs, 1949) into the results of vitamin A deficiency, from 6 months to I or 2 years in duration, involve small numbers under conditions of diet and environment far removed from those to which the subjects are accustomed.

The confusion which may arise in assessing the effects of deficiencies of single nutrients has often been due to a failure to appreciate the importance of the interaction of one nutrient with another in the prevention of pathological processes. Examples are the interdependence of sulphur-containing amino-acids and tocopherol in the prevention of liver necrosis (Gyorgy, 1947; Himsworth \& Lindan, 1949), and the interrelationship of vitamins $\mathrm{A}$ and $\mathrm{C}$, about which conflicting views are expressed (Vedder \& Rosenberg, 1938; Mayer \& Krehl, 1948; Sharman, 1949). New knowledge of antivitamins and of intestinal synthesis of vitamins has greatly modified previous simple views of the development of deficiencies (Kodicek, 1948-9). In reviewing surveys of nutritional status carried out in the United Kingdom from the beginning of the second World War up to I945, Marrack (1948-9) said that 'we need base-lines from which to make comparisons' and 'we need to study groups of individuals, not only by making laboratory investigations, but also by finding out what they eat, how well they are, and what happens to them in the future'.

This nutritional study is the continuation of an attempt to record what Nigerian peasants eat, and to correlate their states of health and present diets. It is hoped that the data presented may be of value to others interested in the problems, both nutritional and administrative, which are associated with undernutrition in tropical communities.

\section{METHODS AND RESULTS}

\section{Plan and scope of the investigation}

The first part of the investigation (Nicol, 1949) was carried out in Northern Nigeria, on three groups of peasants whose staple foodstuffs were grains (Sorghum vulgare and Penisetum typhoideum). One of the groups obtained plentiful supplies of carotene from 
red palm oil, whereas the other two consumed very little of this nutrient. One group, as a result of a larger intake of sorghum, ingested more riboflavin than the others. These grain diets all contained ample amounts of aneurin and nicotinic acid, and provided adequate calories for normal physical exertion. From correlating differences in the diets with the clinical features presented by the different tribes, certain conclusions were drawn concerning the effects of deficiencies of vitamin $A$ and riboflavin upon the physical status of these peoples.

The observations here recorded for the first time were made in Southern Nigeria among two tribes living in the Niger Delta, one being Ijaw fishermen and the other Urhobo farmers. As the staple foodstuffs of these tribes are starchy roots and fish it was believed that the intake of B-complex vitamins, including aneurin and nicotinic acid, would be low and that comparison of the clinical features presented by the southern tribes with those recorded in the northern areas would give some indication of the results of specific deficiencies of aneurin and nicotinic acid. Further, it was considered that information of value might be obtained from the association, in the diets of the fishermen, of a high intake of animal protein with a low intake of B-complex vitamins. For comparison a group of wealthy southern Nigerian traders, mixed Urhobo and Ijaw, was similarly investigated. The diets eaten by these traders are more liberal and varied than those of the peasants.

The clinical and dietary survey was carried out in I949 and I950 in Warri Province. The Ijaw fishermen live in Soragbemi, a village situated on one of the creeks of the Niger Delta, in mangrove swamp, $5^{\circ} 30^{\prime} \mathrm{N} ., 5^{\circ} 30^{\prime} \mathrm{E}$. The Urhobo farmers live in Illu, a village on the borders of the freshwater swamp and high forest zones, $5^{\circ} 40^{\prime} \mathrm{N}$., $6^{\circ} 10^{\prime} \mathrm{E}$. The traders live in the comparatively civilized township of Warri, $5^{\circ} 30^{\prime} \mathrm{N}$, $6^{\circ} \mathrm{o}^{\prime} \mathrm{E}$. The climate is hot and moist throughout the year, with an annual rainfall of 120-180 in. The whole district is only a few feet above sea-level.

The tribes examined in 1947 and 1948 (Nicol, 1949) live in villages in the zones of guinea- and sudan-savannah, between $9^{\circ}$ and $12^{\circ} \mathrm{N}$., and 500-r400 ft. above sealevel, in a much drier climate with a mean annual rainfall of $40-60$ in.

Thus the whole investigation provides information on the diets and the clinical features of five groups of peasants and of one group of wealthy traders as follows:

$\begin{array}{cll}\text { Region } & \text { District } & \text { Occupation } \\ \text { Northern Nigeria } & \text { Bida } & \text { Farmers } \\ & \text { Kontagora } & \text { Farmers } \\ & \text { Zuru } & \text { Farmers } \\ \text { Southern Nigeria } & \text { Soragbemi } & \text { Fishermen } \\ & \text { Illu } & \text { Farmers } \\ & \text { Warri } & \text { Traders }\end{array}$

\section{Southern families whose diets were investigated}

\section{Dietary studies}

Three typical families in each area were selected for investigation. All food eaten by the adults of the compounds was weighed and measured for three periods of 7 days throughout the year April 1949 to April 1950, the periods being selected in accordance with the seasonal availability of staple foodstuffs. Only individuals 
considered to be 12 years of age or over were included in the investigation, the numbers in the families in each area being as follows: Soragbemi, ten males, thirteen females; Illu, nine males, twelve females; Warri, five males, eight females. All weighing and recording was carried out, under supervision, by a hospital attendant, specially trained for the purpose, with a practical knowledge of local conditions. A balance weighing to $\frac{1}{8} \mathrm{oz}$. was used; the conversion factor to grams was $28 \cdot 35$.

\section{Estimation of intake of food and nutrients}

All foods were weighed in bulk before cooking, and individual helpings were weighed before eating, the amount of each foodstuff, as uncooked weight, being calculated by proportion. When food was eaten from a communal dish, as was frequently the case with dry cassava flour and yams, the amount consumed per caput was calculated by dividing the total quantity eaten by the number of consumers. Food eaten outside the compounds was weighed on the spot, or was estimated by asking the farmer or fisherman to bring back an equal quantity to the compound on his return. The amounts consumed by visitors to the various families were allowed for by this method of calculating individual intakes at each meal. The mean daily intake per caput for each group throughout the year was calculated from the figures for each period of investigation and from these data the nutrient and energy values were determined by using Platt's (1945) tables of representative values, additional values being taken from Nicholls (1945), McLester (1949), and from the tables of the Food and Agriculture Organization of the United Nations (Chatfield, 1949).

Estimations of the edible portions, percentage waste and moisture content of certain foodstuffs, e.g. monkey meat, porcupine and some of the larger fishes, were made in the Warri Hospital laboratory. The alcohol content of locally distilled spirits was estimated by analysis of samples from the villages, and the mean value was found to be $60 \%$. I am indebted to the Laboratory Service for these figures.

\section{Consideration of the diets eaten}

The staple foodstuffs of the farmers and fishermen in the southern areas are cassava and yam. The fishermen eat large amounts of fish, but the farmers eat smaller quantities of fish and supplement their protein ration with meat from small land animals, porcupine, pangolin, monkey and snails. Yams are more important than cassava in the diet of the farmers, the converse being the case with the fishermen. Pulses are used in small quantities by the farmers. Apart from peppers, fresh vegetables are seldom cultivated by the peasants in Warri Province, and wild-growing herbs rarely used. Palm oil is plentiful and is the only cooking fat. Fruit is seldom, if ever, eaten.

Palm wine, tapped from the red-oil palm (Elaeis guineensis Jacq.) is the main beverage used by the farmers; the fishermen drink large amounts of 'illicit gin', distilled from palm wine, sweet potatoes and plantains.

The foodstuffs eaten by the farmers, fishermen and traders in the southern region during 1949-50 are shown in Table I. For details of the foodstuffs of the tribes in the northern region in $1947-8$ see Nicol (1949). 
Table I. Average daily food consumption of Southern Nigerian peasant farmers, fishermen and traders, based on a survey of adults in Warri Province, 1949 and $195^{\circ}$

Foodstuff

Wheat flour $(70 \%)$

Rice, milled

Maize: mature yellow immature

Cassava: flour starch 'fufu' fresh tuber

Yam

Cocoyam

Plantain, green

Banana

Sweet potato

Cow pea

Jak fruit

Groundnuts

Pumpkin seed

Coconut kernel

Oil-bean kernel

Dika-nut kernel

Kola-nut kernel

Onions

Okra, fresh

Green leaves from bush

Peppers, red: dry fresh

Tomato, fresh green, fresh

Avocado pear

Guava

Mango

Pawpaw

Orange

Custard apple

Beef

Mutton

Pork, fat

Liver

Eggs

Fish": fresh dried

Shrimps, dry

Prawns, fresh

Oysters, local

Goat

Monkey, dried

African snail

Palm weevils

Frogs' legs

Pangolin

Porcupine

Cane rat

Giant Gambian rat
Scientific name

Triticum vulgare Host Cultigen

Oryza sativa Linn.

Zea mays Linn.

Manihot utillissima Pohl.

Dioscores sativa Linn.

Colocasia antiquorum Schott.

Musa paradisiaca Linn.

$M$. sapientium Linn.

Ipomoea batatas Linn.

Vigna sinensis

Artocarpus integer Merr.

Arachis hypogaea Linn.

Cucurbita spp.

Cocos nucifera Linn.

Pentaclethra macrophylla Bth.

Irvingia gabonensis Baill.

Kola acuminata Schott. and Endl.

Allium cepa Linn.

Hibiscus esculentus Linn.

Corchorus spp., amaranthus spp. and others

Capsicum frutescens Bl.

Lycopersicum esculentum Mill.

Persea americana Mill.

Psidium guajava Linn.

Mangifera indica Linn.

Carica papaya Linn.

Citrus sinensis sp.

Annona reticulata Linn.

$\begin{array}{ccc}\text { Warri } & \text { Illu } & \text { Soragbemi } \\ \text { traders } & \text { farmers } & \text { fishermen }\end{array}$

(g) (g) (g)

$70-\quad-$

76

30

I0

109

102

-

300

$\underline{-17}$

17

22

$-$

15

7

4

2

I

3

4
6

12

3

2

5

4

26

20

12

IO

96

12

16

4

10

62

28

2

$-$

Various species

Archachatina sp.

Rhynchophorus phoenicis

Rana mascarenensis

Manis longicaudata and $M$. tricuspis

Aterurus africanus

Thryonomys swinderianus

Cricetomys gambianus

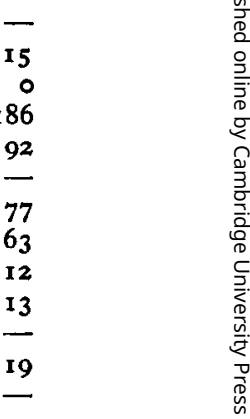

* Mixed lake and estuary. 
Foodstuff

Sardines, tinned

Milk: sweetened condensed

Palm oil evaporated

Margarine

Sugar-cane, stem

Jams, imported

Palm wine (ml.)

'Illicit gin' (ml.)

Gin, European (ml.)

Whisky (ml.)

Brandy (ml.)

Beer, imported (ml.)

Tea

Coffee

Nut (Urhobo-'ewoie')

Salt: imported mangrove
Table I (cont.)

\begin{tabular}{|c|c|c|c|}
\hline Table I (cont.) & $\begin{array}{l}\text { Warri } \\
\text { traders } \\
(\mathrm{g})\end{array}$ & $\begin{array}{c}\text { Illu } \\
\text { farmers } \\
\text { (g) }\end{array}$ & $\begin{array}{l}\text { Soragbemi } \\
\text { fishermen } \\
\text { (g) }\end{array}$ \\
\hline- & 3 & - & - \\
\hline - & 5 & - & - \\
\hline- & 28 & - & - \\
\hline From Elaeis guineensis Jacq. & 36 & 35 & 27 \\
\hline- & 5 & - & - \\
\hline Saccharum officinarum Linn. & 26 & 3 & 4 \\
\hline $\begin{array}{l}\text { From Elaeis guineensis and Raphia } \\
\text { vinifera }\end{array}$ & 120 & 250 & 103 \\
\hline- & 20 & 13 & 107 \\
\hline - & 26 & - & - \\
\hline - & 23 & - & - \\
\hline - & I5 & - & 一 \\
\hline - & 100 & - & - \\
\hline - & 4 & - & - \\
\hline - & 3 & - & - \\
\hline-- & - & $\mathbf{I}$ & $\mathbf{I}$ \\
\hline - & Io & 5 & 7 \\
\hline - & 4 & 3 & 4 \\
\hline
\end{tabular}

\section{Preparation and cooking of foodstuffs}

Two main meals, morning and evening, are eaten by the farmers and fishermen. The traders tend to conform to the three-meal pattern of the United Kingdom, with a snack or tea in the morning and afternoon.

The methods of preparing cassava in the southern areas are as follows. 'Garri', or flour, is made by sieving freshly peeled tubers through fine-meshed, home-made sieves, and drying the resulting pulp in wide basins over charcoal or wood fires. The flour contains very little moisture, and the vitamin content is low. It is boiled with a little water and made into a paste or gruel. 'Farina', another preparation of flour, is made by sieving fresh cassava tubers and wrapping the pulp in wicker baskets or leaves and then pressing these bags between heavy stones for 2 days to express the moisture. Then the pulp is teased out and sun-dried for 8-10 h. The resulting cake, hard and friable, is stored in sacks. It is eaten either dry or moistened, or used in place of 'garri' to make gruel. 'Starch' is prepared by heating pounded cassava with water in an open pot, and squeezing the dough through a cloth or fine wicker-work bag, the filtrate being heated in a pan until the starch sets. It is then wrapped in plantain leaves, and is eaten either cold or heated, or made into a paste with hot water. ' $F u f u$ ' is made by soaking whole tubers in a stream or pond for 2 or 3 days, peeling the rotting root and then sieving or pounding into a paste, which is boiled with a little water before eating.

Yams are prepared for cooking by peeling and slicing or pounding, and are eaten after boiling for about an hour. Sometimes yams are fried in palm oil or roasted in wood ashes.

The soups used by both farmers and fishermen have little variety, consisting almost invariably of peppers, palm oil, meat or fish and salt, either imported or made from mangrove or other wood ash. Edible earths are not used in this province. 
Palm fruit is used in two ways. In one the fruit is boiled in water for about $20 \mathrm{~min}$ and kneaded to remove the pulp from the kernel. This watery pulp, containing oil and the fibrous stroma of the fruit, is the basis of most soups. In the second the watery pulp is simmered and skimmed; the oil so obtained is used for frying fish or yams and bottled for sale in the local markets. Many estimations in the villages showed that these methods yield about $\mathrm{I} \frac{1}{2} \mathrm{oz}$. oil from $\mathrm{I} \mathrm{lb}$. palm fruit, the weight of kernels remaining being $1 \mathrm{I}-\mathrm{I} 2 \mathrm{oz}$. In calculating the nutrient value of palm oil as used in the diets, it was taken that $\mathrm{I}$ lb. fruit yields $\mathrm{I}_{2} \frac{\mathrm{oz}}{\mathrm{oz}}$ oil.

Fish, dried or fresh, is usually boiled, but occasionally fried or roasted. It is seldom eaten raw.

The fishermen often mix ground peppers with the grated kernel of a nut (Urhobo'ewoie') which has not been identified botanically. The farmers allow the kernel of the oil bean tree to ferment before making it into a cake or savoury flavouring for soups. The amounts of these two foodstuffs used by the peasants are small, and it is not thought that lack of knowledge of their nutrient composition makes an appreciable difference to the calculated nutrient values of the diets.

\section{Nutrient values of the peasants' diets}

The analysis of the diets, including those of the northern tribes, is shown in Table 2. Allowance has not been made for destruction of nutrients by cooking. It is probable that some aneurin is lost, as fish and yams, the foods providing most, are usually boiled and the water discarded. As fish is generally boiled before eating it is unlikely that destruction of aneurin by enzymes derived from the fish itself is an important source of loss (Melnick, Hochberg \& Oser, 1945). If an allowance of $67 \%$ is made for destruction of ascorbic acid in cooking, each of the diets still provides $10 \mathrm{mg}$ or more daily, the amount found by the Medical Research Council (1948) to prevent clinical scurvy, but the Bida farmers alone of the peasants obtain more than the $20 \mathrm{mg}$ recommended by the British Medical Association Committee on Nutrition (1950) as a daily allowance for moderately active adults, and only they reach the figure of $30 \mathrm{mg}$ suggested by Platt (1946) and the Medical Research Council (1948) to be necessary to cover all requirements for active life and inherent individual variability.

Comparisons of the nutritive values of the diets of the six groups has been made with the daily 'allowances' recommended by the (U.S.A.) National Research Council (1948). In these, the mean adult weights of each group have been taken into account, and a reduction of $12 \frac{1}{2} \%$ has been made from the number of calories recommended by the Council to allow for the reduction of basal and total metabolic rates found in tropical climates (Keys, I949). The data have been expressed as Cal./lb. body-weight (Table 3). It was impossible to estimate the energy expenditure of the peasants, but at certain times they are very active, the northern farmers in the fields and when boxing and wrestling, the fishermen when paddling long distances often against strong tides and currents. It seems justifiable to classify all groups as 'moderately active'. Protein intake has been expressed as $\mathrm{g} / \mathrm{lb}$. body-weight (Table 3); aneurin, riboflavin 


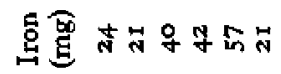

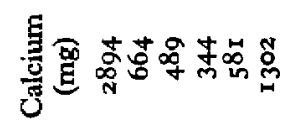

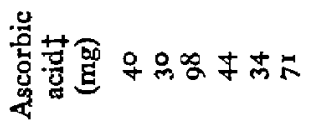

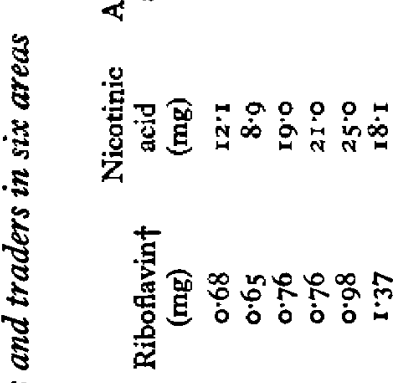

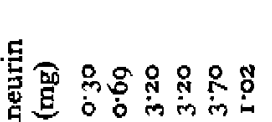

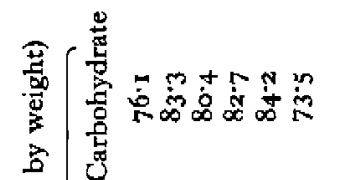

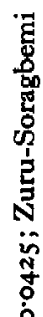

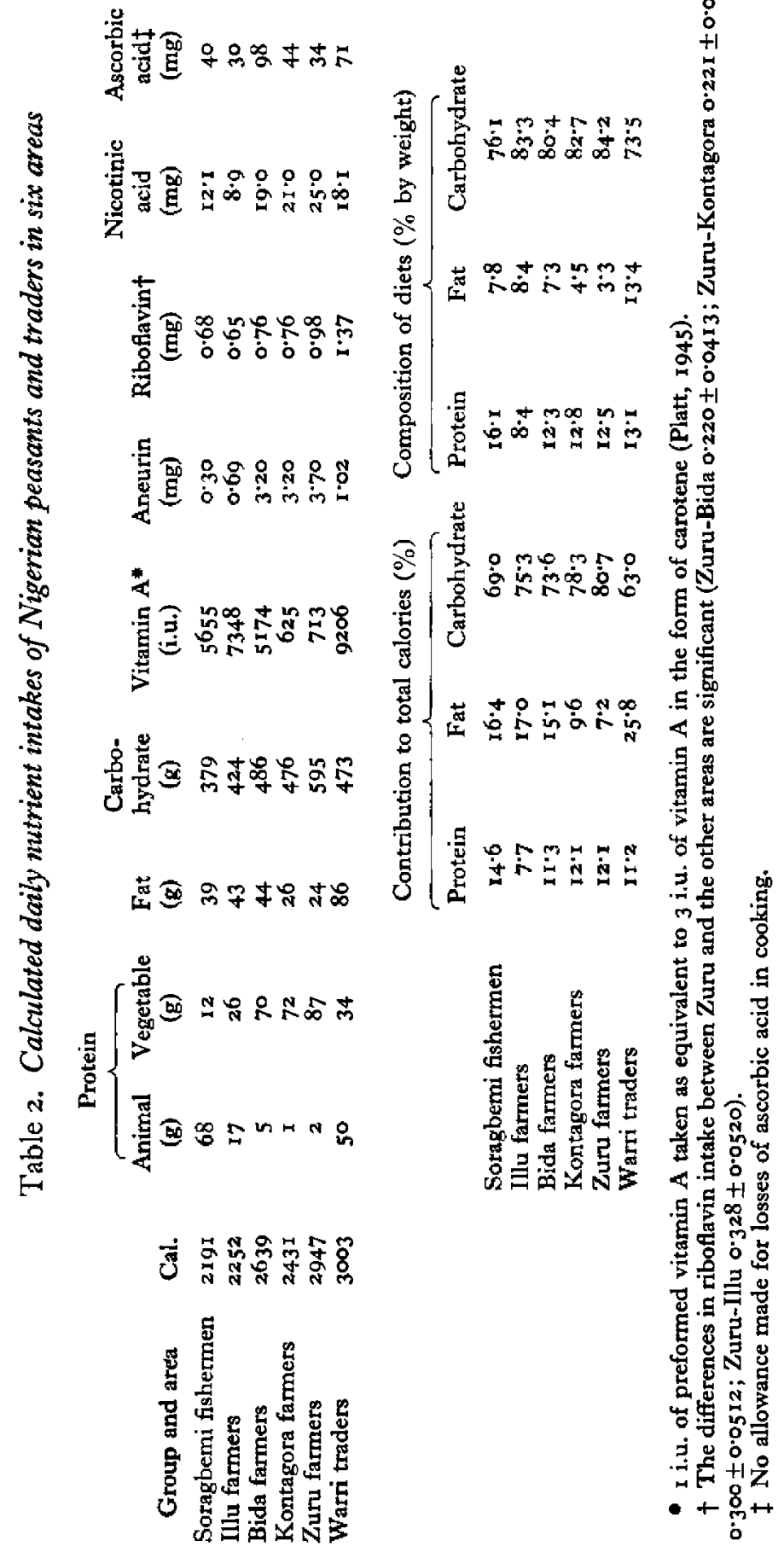


and nicotinic acid as $\mathrm{mg} / \mathrm{lb}$. body-weight and $\mathrm{mg} / \mathrm{ro00}$ Cal., and aneurin also as the ratio aneurin/non-fat Cal. (Passmore, 1948) (Table 4).

From these data, none of the groups appears deficient in calories for 'moderate activity' per lb. body-weight. The Illu farmers are the only group deficient in total protein, but the supply of animal protein to the northern farmers is negligible. The fat content of the peasants' diets, even in the areas where palm oil is plentiful, is less than a third of the amount normally found in good European diets.

Table 3. Calculated amounts of protein and calories supplied by the diets per lb. bodyweight, compared with (U.S.A.) National Research Council recommendations for moderately active men and women of mean weight $139 \mathrm{lb}$., $12 \frac{1}{2} \%$ reduction in calories being allowed for the effect of climate upon basal and total basal metabolic rate (Keys, 1949)

\begin{tabular}{|c|c|c|c|c|c|}
\hline & $\begin{array}{l}\text { Mean weight, } \\
\text { male and } \\
\text { female } \\
\text { (lb.) }\end{array}$ & Cal. & $\begin{array}{l}\text { Total } \\
\text { protein } \\
(\mathrm{g})\end{array}$ & $\begin{array}{l}\text { Animal } \\
\text { protein } \\
\text { (g) }\end{array}$ & $\begin{array}{c}\text { Vegetable } \\
\text { protein } \\
\text { (g) }\end{array}$ \\
\hline Soragbemi fishermen & 119 & $r 8 \cdot 4$ & 0.67 & 0.57 & $0 \cdot 10$ \\
\hline Illu farmers & III & $22 \cdot 9$ & 0.39 & 0.15 & 0.24 \\
\hline Bida farmers & 116 & $22 \cdot 8$ & 0.65 & 0.04 & 0.61 \\
\hline Kontagora farmers & I I 6 & $20 \cdot 6$ & 0.62 & 0.01 & 0.61 \\
\hline Zuru farmers & 117 & $24 \cdot 9$ & 0.76 & 0.02 & 0.74 \\
\hline Warri traders & 136 & $22 \cdot 1$ & 0.62 & 0.37 & 0.25 \\
\hline N.R.C. allowances* & 139 & I $7 \cdot 0$ & 0.47 & 0.31 & 0.16 \\
\hline
\end{tabular}

Calcium is 'deficient' in all peasant diets except that of the fishermen. Iron is present in amounts considered adequate by European standards, but these do not allow for the heavy intestinal infestations and endemic malaria encountered among African peasant populations.

Important differences in vitamin intakes have been noted between one area and another. First, carotene is plentiful in the diets in Bida, Soragbemi and Illu, but scarce in Kontagora and Zuru, owing to the geographical distribution of the red-oil palm. Secondly, the intake of aneurin is very low in Soragbemi and Illu but plentiful in Bida, Kontagora and Zuru, because the staples in the first two areas are starchy roots and in the other three areas sorghum and millet. Thirdly, the intake of nicotinic acid in Soragbemi and Illu is much lower than elsewhere, although that in Soragbemi is 'adequate' judged by National Research Council (1948) standards. Fourthly, the intake of riboflavin is low in all areas, but that in Zuru is $25-35 \%$ higher than in the other areas. This is due to the large quantities of sorghum eaten by the Zuru farmers.

\section{Clinical examination}

\section{Clinical studies}

A clinical examination of all the individuals whose diets were measured, and of others of the same economic status, was carried out in each area. Since Sinclair (I948) doubts the ability of one observer to record clinical signs consistently, great care was 


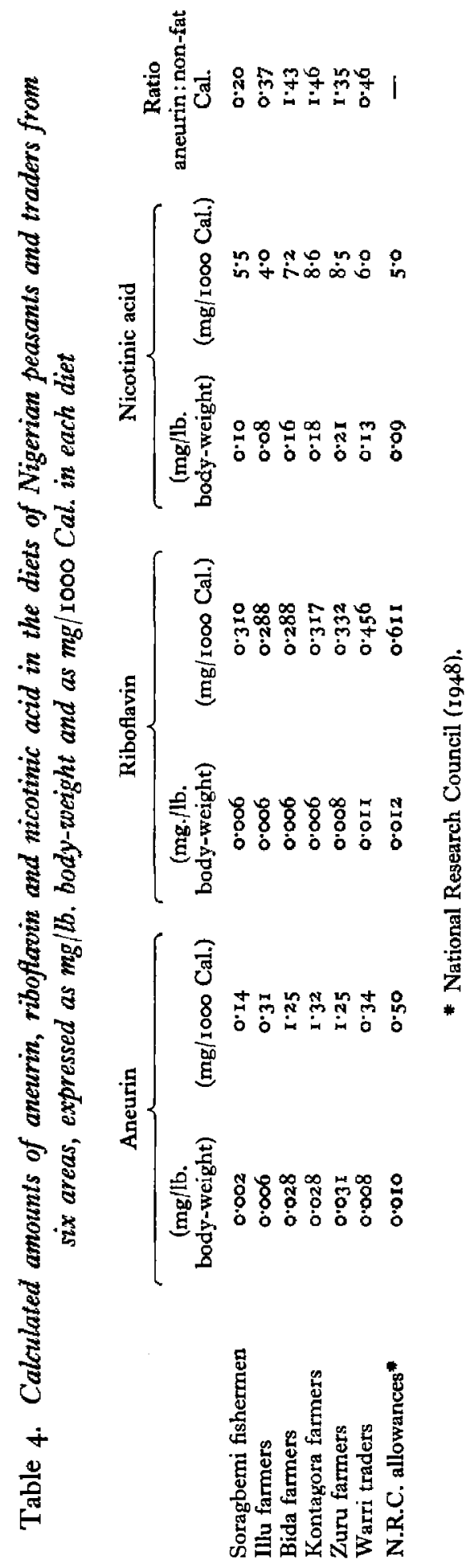


taken to standardize records by constant reference to photographs previously taken. The physical and mental development of the African who assisted at all examinations was also a useful standard reference of health.

The clinical criteria used in the examination are stated in Table 5. Particular care was taken in the examination of the liver, and in questioning each individual about any previous history of jaundice or haematuria. Haemoglobin was estimated by Sahli's method and the instrument was checked against a Haldane haemoglobinometer ( $100 \%$ (Haldane) $=14.8 \mathrm{~g} \mathrm{Hb} / 100 \mathrm{ml}$.) in the United Kingdom at the end of the investigation.

All mothers were questioned regarding the numbers of children alive, stillbirths and miscarriages, and this information was cross-checked with the husbands and neighbours (Table 6).

Microscopic examination of the urine and faeces of samples of each population was carried out in the villages, and the weights of large samples were recorded, using an accurate yard-arm machine.

\section{Clinical findings}

The sex and age incidence of the samples of the population are given in Table 7 . The incidence of clinical abnormalities and the criteria on which they were assessed, are given in Table 5 .

The general appearance of individuals in each sample, the mean haemoglobin levels and the incidence of hepatic disease and of symptoms associated with the aetiology of hepatitis and cirrhosis of the liver are presented in Table 8. The mean weights and sizes of the samples taken are given in Table 9, and the infestation rates and splenic indices in Table ro.

The general appearance of individuals, who were classified into three groups, good, fair, and poor according to mental and physical development and alertness, muscular and skeletal development and any other features disclosed by examination, was found to be best in the Warri traders, the Soragbemi fishermen being a close second, and the Illu and Zuru farmers worst. A significant difference in sex incidence for any of the features considered was not found, but staring hair occurred most often below the age of ro years, and the incidence of pigmentation of the sclera, thickening of the conjunctiva and gingivitis increased with age.

When reporting the nutritional status of the northern tribes the clinical features were grouped into those found most frequently in areas where deficiency of a particular nutrient occurred, or where the deficiency was of greater degree than elsewhere (Nicol, 1949). In this report the same method has been applied and extended to include the southern populations, with the object, first, of confirming or otherwise the conclusions previously drawn concerning the effects of deficiencies of vitamin A and riboflavin and, secondly, of comparing the incidence of features found in areas where the supply of aneurin and nicotinic acid is low with that occurring in areas where these nutrients are plentiful. This grouping of the clinical features is given in Table Ir. 


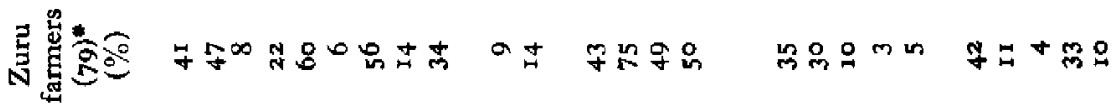
हू

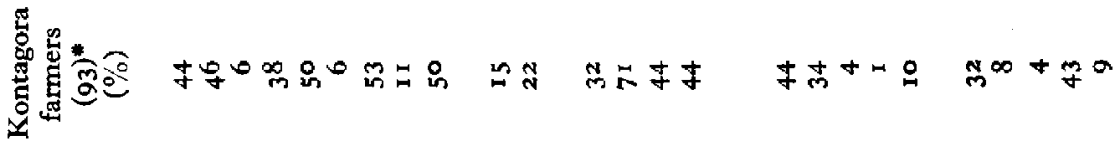

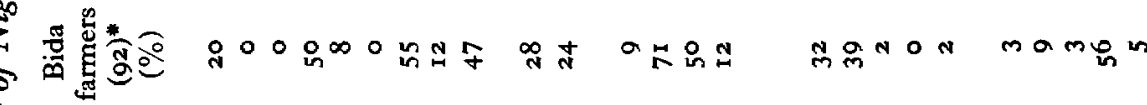

है

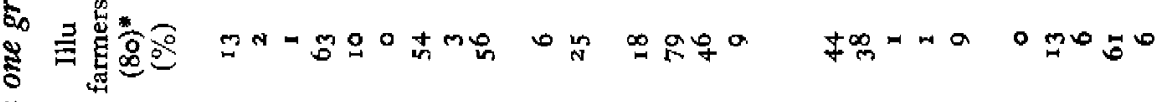
.

है

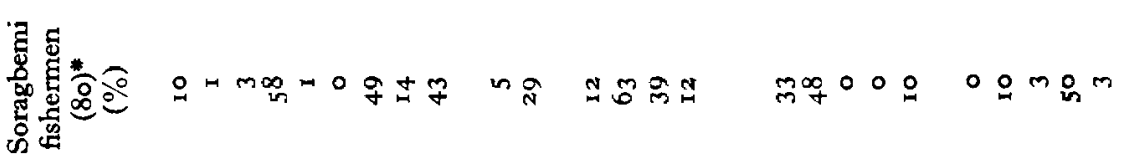

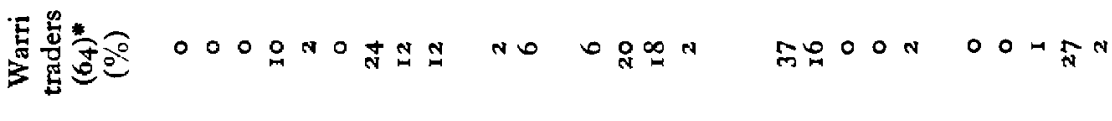

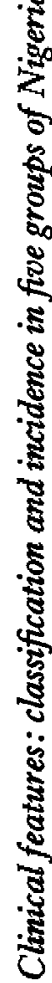

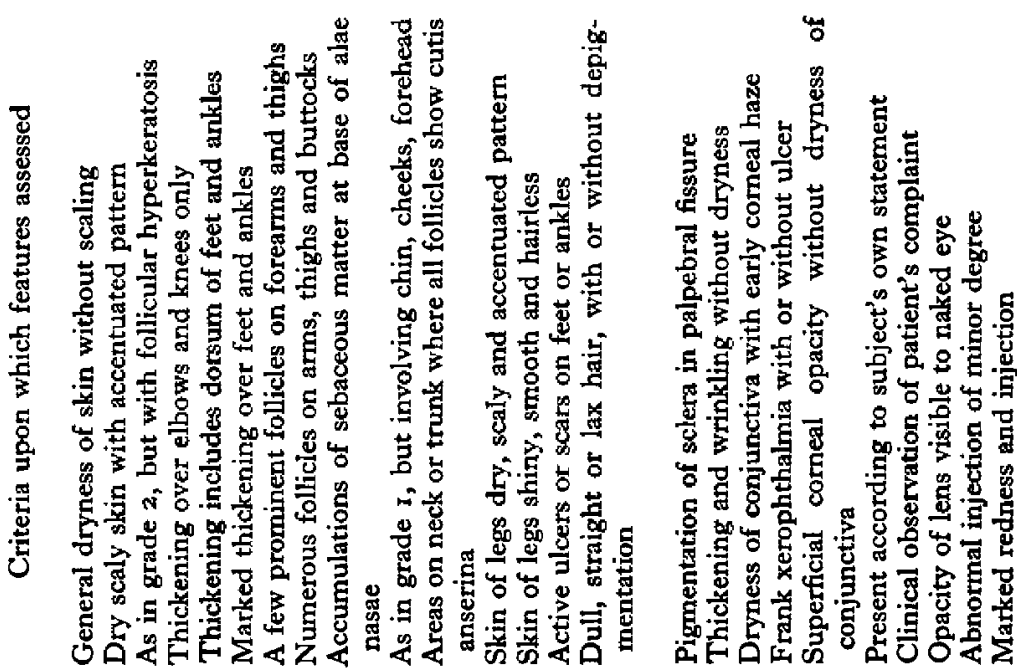

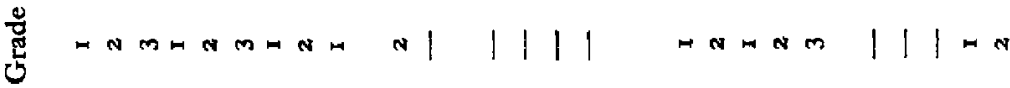
in

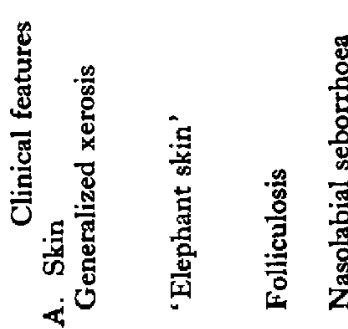

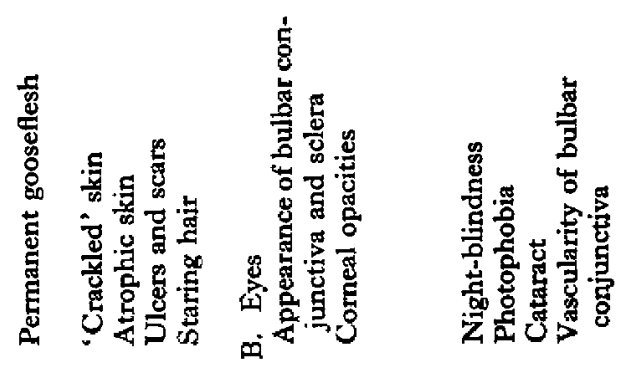




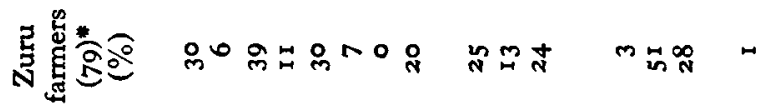
连营

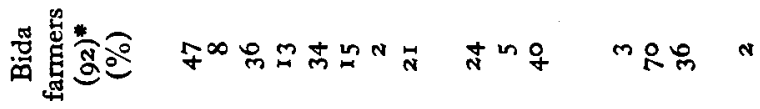

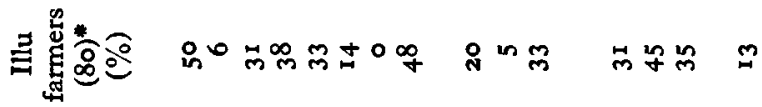

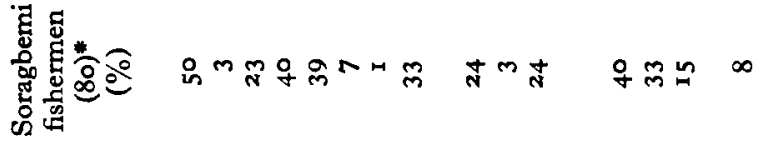

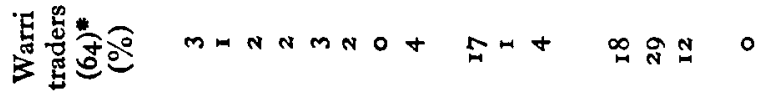
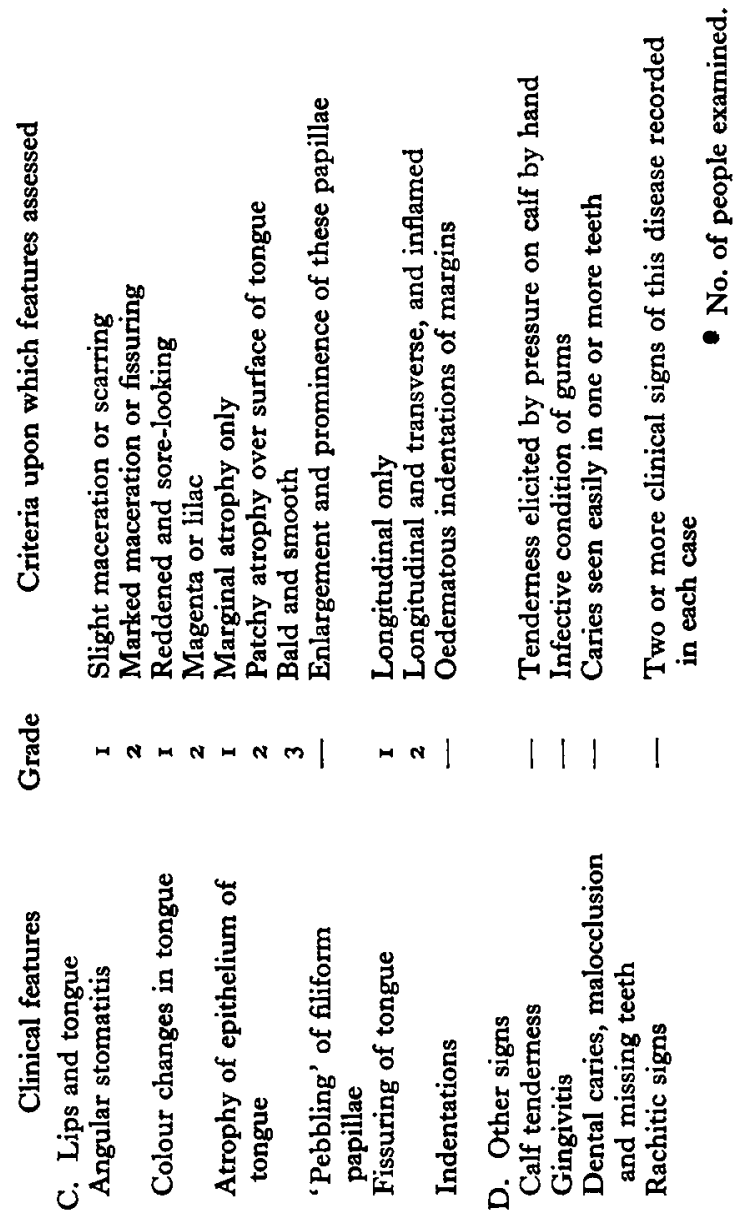
Table 6. Child mortality and failed pregnancies in five areas in Nigeria

\begin{tabular}{|c|c|c|c|c|c|c|}
\hline & \multirow{2}{*}{$\begin{array}{l}\text { No. of } \\
\text { mothers }\end{array}$} & \multirow{2}{*}{$\begin{array}{l}\text { No. of } \\
\text { children } \\
\text { alive }\end{array}$} & \multicolumn{3}{|c|}{ Children dying between birth and } & \multirow{2}{*}{$\begin{array}{l}\text { Infant- } \\
\text { mortality } \\
\text { rate }\end{array}$} \\
\hline & & & I year & 5 years & over 5 years & \\
\hline Soragbemi fishermen, $1949-50$ & 44 & 100 & 68 & 12 & 16 & 347 \\
\hline Illu farmers, I949-50 & 36 & 54 & 54 & $\mathrm{I} 2$ & 6 & 429 \\
\hline Bida farmers, $1947^{-8}$ & $4 \mathrm{I}$ & 72 & 30 & 7 & 9 & 254 \\
\hline Kontagora farmers, $1947-8$ & 30 & 87 & 55 & 8 & 7 & $35 \mathrm{I}$ \\
\hline Zuru farmers, $1947-8$ & 26 & 36 & 32 & 9 & 7 & 276 \\
\hline
\end{tabular}

Abortions, miscarriages and stillbirths: Soragbemi, 12; Illu, 12; Bida, 24; Kontagora, 14; Zuru, 16.

Table 7. Age and sex incidence of samples of the population examined clinically in six areas of Nigeria

\begin{tabular}{|c|c|c|c|c|c|c|c|c|c|c|c|c|c|}
\hline \multirow[b]{2}{*}{ District } & \multicolumn{2}{|c|}{$\begin{array}{l}0-10 \\
\text { years }\end{array}$} & \multicolumn{2}{|c|}{$\begin{array}{l}\text { II-20 } \\
\text { years }\end{array}$} & \multicolumn{2}{|c|}{$\begin{array}{l}21-30 \\
\text { years }\end{array}$} & \multicolumn{2}{|c|}{$\begin{array}{l}3 I-40 \\
\text { years }\end{array}$} & \multicolumn{2}{|c|}{$\begin{array}{l}4 \mathrm{I}-50 \\
\text { years }\end{array}$} & \multicolumn{2}{|c|}{$\begin{array}{c}\text { Over } 50 \\
\text { years }\end{array}$} & \multirow[b]{2}{*}{ Total } \\
\hline & M. & F. & M. & F. & M. & F. & $\mathbf{M}$ & F. & M. & F. & M. & F. & \\
\hline Soragbemi & 5 & 6 & 8 & 8 & 10 & 8 & 10 & 6 & 6 & 4 & 5 & 4 & 80 \\
\hline Illu & 4 & 3 & 10 & 9 & 9 & II & 9 & 8 & 6 & 5 & 3 & 3 & 80 \\
\hline Bida & 4 & 4 & I I & 9 & I I & 17 & 8 & 9 & 6 & 6 & 4 & 3 & 92 \\
\hline Kontagora & 8 & 9 & I7 & 14 & 6 & 8 & 6 & II & 2 & 5 & 4 & 3 & 93 \\
\hline Zuru & 6 & 7 & 13 & 7 & 8 & 7 & 6 & 8 & 6 & 4 & 4 & 3 & 79 \\
\hline Warri & 2 & 3 & 6 & 4 & 6 & 5 & 6 & I0 & 7 & 8 & 4 & 3 & 64 \\
\hline & & & & & & & & & & & To & & 488 \\
\hline
\end{tabular}

M. male; F. female.

Table 8. General appearance, incidence of disorders of the liver, mean haemoglobin levels, of five groups of Nigerian peasants and one group of Nigerian traders

\begin{tabular}{|c|c|c|c|c|c|c|}
\hline & $\begin{array}{c}\text { Warri } \\
\text { traders } \\
(64)^{*} \\
(\%)\end{array}$ & $\begin{array}{c}\text { Soragbemi } \\
\text { fishermen } \\
(80)^{*} \\
(\%)\end{array}$ & $\begin{array}{c}\text { Illu } \\
\text { farmers } \\
(80)^{*} \\
(\%)\end{array}$ & $\begin{array}{c}\text { Bida } \\
\text { farmers } \\
(92)^{*} \\
(\%)\end{array}$ & $\begin{array}{c}\text { Kontagora } \\
\text { farmers } \\
(93)^{*} \\
(\%)\end{array}$ & $\begin{array}{c}\text { Zuru } \\
\text { farmers } \\
(79)^{*} \\
(\%)\end{array}$ \\
\hline General appearance: good & 70 & 67 & 38 & 47 & 43 & 38 \\
\hline & 26 & $3^{\circ}$ & 56 & 47 & 48 & 46 \\
\hline poor & 4 & 3 & 6 & 6 & 9 & 16 \\
\hline $\begin{array}{l}\text { Clinically demonstrable liver } \\
\text { disease }\end{array}$ & 3 & 8 & 19 & 15 & 12 & 9 \\
\hline Previous history of jaundice & 3 & 8 & 6 & 5 & 6 & 6 \\
\hline Previous history of haematuria & I & I & 0 & 9 & 3 & 6 \\
\hline Mean $\mathrm{Hb}$ readings & 82 & 76 & 70 & 70 & 73 & 76 \\
\hline $\begin{array}{l}\text { Standard deviation } \\
\text { Standard error of mean }\end{array}$ & $\begin{array}{r}11 \cdot 80 \\
1 \cdot 48\end{array}$ & $\begin{array}{r}\text { II } \cdot 80 \\
I \cdot 32\end{array}$ & $\begin{array}{r}10.60 \\
1 \cdot 19\end{array}$ & $\begin{array}{r}10.62 \\
1 \cdot 13\end{array}$ & $\begin{array}{r}10.90 \\
I \cdot I I\end{array}$ & $\begin{array}{r}11 \cdot 95 \\
1 \cdot 3^{6}\end{array}$ \\
\hline \multicolumn{7}{|c|}{ * No. of people examined. } \\
\hline \multicolumn{7}{|c|}{$\begin{array}{c}\text { Table 9. Mean weights of five samples of the peasant population of Nigeria, } \\
\text { and of one sample of wealthy native traders }\end{array}$} \\
\hline & $\begin{array}{l}\text { Warri } \\
\text { traders } \\
(484)^{*}\end{array}$ & $\begin{array}{l}\text { Soragbemi } \\
\text { fishermen } \\
(757)^{*}\end{array}$ & $\begin{array}{l}\text { Illu } \\
\text { farmers } \\
(1085)^{*}\end{array}$ & $\begin{array}{c}\text { Bida } \\
\text { farmers } \\
(638)^{*}\end{array}$ & $\begin{array}{l}\text { Kontagora } \\
\text { farmers } \\
(702)^{*}\end{array}$ & $\begin{array}{c}\text { Zuru } \\
\text { farmers } \\
(685)^{*}\end{array}$ \\
\hline Mean weight (lb.) & 136 & 119 & III & II6 & 116 & $I I 7$ \\
\hline $\begin{array}{l}\text { Standard deviation } \\
\text { Standard error of mean }\end{array}$ & $\begin{array}{r}22 \cdot 90 \\
1 \cdot 04\end{array}$ & $\begin{array}{r}12.65 \\
0.46\end{array}$ & $\begin{array}{r}15.85 \\
0.48\end{array}$ & $\begin{array}{r}13.64 \\
0.53\end{array}$ & $\begin{array}{r}12.80 \\
0.48\end{array}$ & $\begin{array}{r}11 \cdot 98 \\
0.46\end{array}$ \\
\hline
\end{tabular}

* Number in sample, ages $16-65$ years. 
Table ro. Percentage incidence of parasitic infestations in six areas of Nigeria

$\begin{array}{lcccccc} & \begin{array}{c}\text { Warri } \\ \text { traders } \\ (100)^{*}\end{array} & \begin{array}{c}\text { Soragbemi } \\ \text { fishermen } \\ (150)^{*}\end{array} & \begin{array}{c}\text { Illu } \\ \text { farmers } \\ (150)^{*}\end{array} & \begin{array}{c}\text { Bida } \\ \text { farmers } \\ (200)^{*}\end{array} & \begin{array}{c}\text { Kontagora } \\ \text { farmers } \\ (200)^{*}\end{array} & \begin{array}{c}\text { Zuru } \\ \text { farmers } \\ (200)^{*}\end{array} \\ \text { Ankylostomiasis } & 73 & 96 & 95 & 95 & 57 & 65 \\ \text { Ascariasis } & 17 & 20 & 31 & 0 & 6 & 5 \\ \text { S. mansoni } & 0 & 0 & 1 & 0 & 5 & 4 \\ \text { S. haematobium } & 1 & 0 & 1 & 50 & 70 & 39 \\ \text { Trypanosomiasis } & \circ & \circ & 0 & 15 & 0 & 0 \\ \text { Dracontiasis } & \circ & 0 & 0 & \text { Infrequent } & \text { Frequent } & \text { Frequent } \\ \text { Splenic index 2-10 years, } & 17 & 17 & 22 & 20 & 15 & 17 \\ \text { I00 children in each area } & & & & & & \end{array}$

(I am indebted to Dr O. D. Macnamara for his figures concerning the infestation rates in Bida, Kontagora and Zuru, reported in $1945^{-6}$.)

- No. of people examined.

\section{DISCUSSION}

The incidence of hepatic disease and anaemia, which is almost always hypochromic and microcytic in type, was high, but the major nutritional diseases, beri-beri, pellagra and scurvy have not been encountered. However, the minor stigmata associated with nutritional deficiencies have been recorded very often.

The high rate of intestinal infestations (Table 10), particularly with hookworms, round-worms and schistosomes, is considered to be a more important factor in the production of anaemia than dietary deficiencies. Distinct from the loss of blood caused by these parasites is the amount of nutriment of which they deprive the host. Chance \& Dirnhuber (1949) have shown that nematodes, trematodes and cestodes all contain large amounts of B-complex vitamins. For instance, analysis of Ascaris lumbricoides revealed $13.5 \mu \mathrm{g}$ riboflavin, $10 \mu \mathrm{g}$ aneurin and $200 \mu \mathrm{g}$ nicotinic acid per $100 \mathrm{~g}$ dry weight of whole worm. They believe that the parasites absorb large quantities of these vitamins from the gut lumen. After a vermifuge, an African may pass some hundreds of ascaris and the effect of these upon the supplies of B-complex vitamins, whether ingested or synthesized in the intestine, must be considerable.

The numbers of peasants suffering from schistosomiasis was much lower in the south than in the north, and it was expected, as a result, that the incidence of cirrhosis of the liver would be less in this region. This has not been found, and it appears probable that nutritional factors are the chief cause of the high incidence of this disease in all areas.

\section{Specific vitamin deficiencies}

The clinical data, grouped as described on p. 43 and presented in Table II, confirm the earlier conclusions that vitamin A deficiency results in dryness and depigmentation of the hair, general xerosis, follicular hyperkeratosis, 'elephant skin', 'crackled' skin and night-blindness. Corneal opacity is considered below. Many individuals showing all grades of xerosis, 'elephant skin' and 'crackled' skin have been found among those tribes whose diets contain ample quantities of carotene. It is believed that, in certain cases, these signs may result from a deficiency of ascorbic acid, and in others from an inability to utilize vitamin $A$ as a result of disturbed liver 
Table I I. Grouping, according to nutrient intakes, of the clinical features observed in peasants from five areas of Nigeria

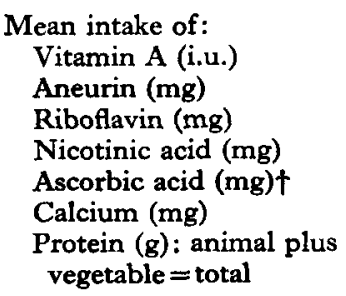

$\begin{array}{ccccc}\begin{array}{c}\text { Soragbemi } \\ \text { fishermen } \\ (80)^{*}\end{array} & \begin{array}{c}\text { Illu } \\ \text { farmers } \\ (80)^{*}\end{array} & \begin{array}{c}\text { Bida } \\ \text { farmers } \\ (92)^{*}\end{array} & \begin{array}{c}\text { Kontagora } \\ \text { farmers } \\ (93)^{*}\end{array} & \begin{array}{c}\text { Zuru } \\ \text { farmers } \\ (79)^{*}\end{array} \\ 5655 & 7348 & 5174 & 624 & 713 \\ 0.30 & 0.69 & 3.20 & 3.20 & 3.70 \\ 0.68 & 0.65 & 0.76 & 0.76 & 0.98 \\ 12.1 & 8.9 & 19.0 & 21 \cdot 0 & 25.0 \\ 26.7 & 10.0 & 32.7 & 14.7 & 11 \cdot 3 \\ 2894 & 664 & 489 & 344 & 581 \\ 68+12=80 & 17+26=43 & 5+70=75 & 1+72=73 & 2+87=89\end{array}$

Clinical features (percentage incidence)

Folliculosis

Atrophic skin

Ulcers and scars of ulcers

Thickened conjunctiva

Photophobia

Fissuring of tongue

Oedema of tongue

Corneal opacity, grade 3

Group I : roughly same incidence in each area

Group 2: more frequent in Kontagora and Zuru than elsewhere

$\begin{array}{rrrrr}63 & 57 & 67 & 64 & 70 \\ 63 & 79 & 7 r & 71 & 75 \\ 39 & 46 & 50 & 44 & 49 \\ 48 & 38 & 39 & 34 & 30 \\ 13 & 10 & 9 & 8 & 11 \\ 27 & 25 & 29 & 35 & 38 \\ 24 & 33 & 40 & 20 & 24 \\ 10 & 9 & 2 & 10 & 5\end{array}$

$\begin{array}{lcc}\text { Kontagora } & \begin{array}{c}\text { Soragbemi, Illu } \\ \text { and Zuru } \\ \text { and Bida }\end{array} & \text { I r } \\ \text { 'Crair dry and staring } & 47 & 13 \\ \text { Xerosis, all grades } & 37 & 5 \\ \text { 'Elephant skin', grades 2 and 3 } & 32 & 6 \\ \text { Corneal opacity, grade I } & 6 \mathbf{1} & \text { I } \\ \text { Night-blindness } & 7 & \text { I }\end{array}$

Group 3 : less frequent in Zuru than elsewhere

$\begin{array}{cc}\begin{array}{c}\text { Soragbemi, Illu, } \\ \text { Bida and } \\ \text { Kontagora }\end{array} & \text { Zuru } \\ 63 & 43 \\ 25 & 14 \\ 60 & 48 \\ 56 & 36\end{array}$

Group 4: more common in Soragbemi and Illu than elsewhere

Nasolabial seborrhoea

Permanent gooseflesh

Injection of conjunctiva

Angular stomatitis

$$
\begin{aligned}
& \text { Soragbemi } \\
& \text { and Illu }
\end{aligned}
$$

Calf tenderness

Magenta and lilac tongues

Signs of rickets

$\begin{array}{rr}36 & 3 \\ 39 & 12 \\ 11 & 1\end{array}$

Group 5: more common in Illu than elsewhere

$\begin{array}{ccc}\text { Enlargement of filiform papillae of tongue } & \text { Illu } & \begin{array}{c}\text { Soragbemi, } \\ \text { Kontagora } \\ \text { Bida and Zuru }\end{array} \\ \text { Group 6: Less common in Soragbemi than elsewhere } & 26 \\ & \begin{array}{c}\text { Illu, Bida, Zuru } \\ \text { and Kontagora }\end{array} & \text { Soragbemi } \\ \text { Red, sore-looking tongues } & 37 & 23 \\ \text { Dental caries } & 32 & 15\end{array}$

Significance: $P=0.05$ for each of the clinical features considered in groups 2-6.

- No. of people examined.

$+67 \%$ allowance made for destruction of ascorbic acid in cooking. 
function or lack of fat to aid absorption of carotene. Analysis of those cases with severe clinical disorders of the liver showed that a high percentage presented the skin signs of vitamin A deficiency, corneal opacity and dryness of the conjunctiva, despite an adequate intake of carotene.

The figures also confirm the conclusions that riboflavin deficiency leads to the occurrence of angular stomatitis, nasolabial seborrhoea, increased vascularity of the conjunctiva and permanent gooseflesh. Lesions of the cornea resulting from riboflavin deficiency are considered below.

In Soragbemi and Illu it was found that magenta and lilac coloration of the tongue, tenderness of calves and rickets were more frequent than in the other three villages. It is considered justifiable to attribute the tenderness of calves to deficiency of aneurin, but why the other signs fall into this group is obscure.

'Pebbling' of the lingual papillae was observed more frequently in Illu than elsewhere. The intake of nicotinic acid in this area was only two-thirds of that recommended by the (U.S.A.) National Research Council (1948) as a daily allowance. This finding is in accordance with the views of Adamson \& Platt (quoted by Abbott, 1950) that hypertrophy of the mucous membrane of the tongue is an early result of chronic deficiency of nicotinic acid.

Apart from the observations made above that a low intake of ascorbic acid may result in xerosis, follicular hyperkeratosis and 'crackled' skin in some cases, other signs of vitamin $\mathrm{C}$ deficiency were not encountered.

With regard to those signs that were found to occur with equal frequency in all areas (group $\mathrm{I}$, Table I $\mathrm{r}$ ) it is possible that the long-continued ingestion of suboptimal amounts of riboflavin leads to their appearance. Consideration of the clinical features presented by the Warri traders, however, which are discussed below, suggests that some of these signs are not nutritional in origin, but are the result of minor physical trauma.

\section{Corneal opacities}

From a consideration of the literature cited elsewhere (Nicol 1949) it would appear that corneal opacity due to vitamin A deficiency is usually associated with thickening and dryness of the conjunctiva, whereas the superficial keratitis which is held to result from lack of riboflavin is not so associated. The data now available from this investigation are in accordance with these views, superficial corneal opacity being found with equal frequency in all areas, and keratitis accompanied by dryness of the conjunctiva being recorded most often in areas where the carotene intake is low, irrespective of the incidence of cirrhosis of the liver and its effects upon vitamin A metabolism.

\section{Tongue}

The data given in Table I I show that, in the presence of riboflavin deficiency, the changes in the tongue customarily attributed to nicotinic-acid deficiency, namely redness, oedema, hypertrophy or atrophy of the mucosa, can appear in populations 
having ample supplies of this nutrient, and that signs commonly considered to be the result of riboflavin deficiency, e.g. colour changes, occur more frequently in association with a low intake of nicotinic acid than when nicotinic acid is plentiful in the diet. These observations prompt the suggestion that a factor additional to lack of these two nutrients is involved in the production of such pathological conditions of the tongue.

Red, sore-looking tongues were found significantly less often in Soragbemi, where the intake of animal protein was high, than elsewhere, and signs commonly attributed to nicotinic-acid deficiency were often found where nicotinic acid is plentiful but where the intake of animal protein is very low, e.g. in Kontagora. It is suggested, therefore, that the tongue changes found in poorly nourished communities result from the lack of some factor, possibly tryptophan (Anonymous, 1950) present in animal protein, in addition to a quantitative deficiency of riboflavin and nicotinic acid, or to a disturbed relationship between protein and the vitamin B complex. Goldberger \& Tanner (192I), already 30 years ago, believed that tryptophan might be the antipellagra vitamin.

\section{Clinical signs presented by the Warri traders}

The diets of the traders provide ample amounts of all nutrients except aneurin and riboflavin. The calculated mean daily intakes per caput of aneurin $(0.34 \mathrm{mg} / 1000 \mathrm{Cal}$.) and riboflavin $(0.46 \mathrm{mg} / 1000 \mathrm{Cal}$.) are less than those recommended by the (U.S.A.) National Research Council (1948) for moderately active men and women, weighing $139 \mathrm{lb}$. (0.61 mg riboflavin and $0.50 \mathrm{mg}$ aneurin/ $1000 \mathrm{Cal}$.).

Keys et al. (1945) found that young men on diets providing $3300 \mathrm{Cal} ., 0.19 \mathrm{mg}$ aneurin and $0.29 \mathrm{mg}$ riboflavin/I000 Cal. did not show any physical signs of deficiency over periods up to I6I days. Yet the traders frequently suffer from nasolabial seborrhoea, abnormal vascularity of the conjunctiva and tenderness of the calves. There is good evidence for the assumption that these signs are due to a low intake of aneurin and riboflavin, and it is concluded that the amounts of these nutrients ingested by the traders are not enough to cover all the requirements of daily life and inherent individual variability.

Other signs that present themselves frequently in the traders fall into two groups: first, a sign that was recorded as often in the traders as in the peasants, namely pigmentation of the sclera; and secondly, a group of signs that, although recorded frequently in the traders, do not appear among them as often as among the peasants, namely folliculosis, atrophic skin, tropical ulcers, thickening of the conjunctiva, fissuring of the tongue, gingivitis and dental caries. It is concluded that pigmentation of the sclera is unlikely to be nutritional in origin, particularly as its incidence increases with age.

Of the other signs presented by the traders, which cannot be attributed, as a result of this investigation, to any specific nutritional deficiency, it is believed that folliculosis, atrophic skin and thickening of the conjunctiva are due to long-continued minor trauma, e.g. at pressure points for folliculosis, and bright sunlight and 'glare' for thickening of the conjunctiva. Trauma and secondary infection play a part in the 
aetiology of tropical ulcers, and congenital factors in the aetiology of fissuring of the tongue and their effects are difficult to separate from those of undernutrition.

It is concluded that all these signs are largely the result of long-continued minor traumata, but this does not exclude the possibility that deficiency of B-complex vitamins, and particularly of riboflavin, may exaggerate the effects of trauma.

Gingivitis was recorded frequently in all the samples of the population, but was found less often in the south than in the north. This is perhaps due to the more regular use of 'chew-sticks' by the southern natives rather than to lack of any nutrient.

\section{Other clinical features}

Evidence is not available to explain the higher incidence of rickets in the south than in the north. Dental caries was found less often in the fishermen than in the other peasant groups, and this may be the result of the large amounts of calcium in their diet.

Diffuse neuralgic pains, dyspepsia, emotional instability and easy fatigue are symptoms which cause much trouble to both medical and administrative officers. Elsom, Lewy \& Heublein (1940), Williams, Mason \& Smith (1939), Williams, Mason, Wilder \& Smith (1940), Williams, Mason, Smith \& Wilder (1942) and Keys et al. (1945) have all attributed these features to a low intake of aneurin. That such symptoms are more common in the southern peasants than in the northern tribes is in accord with this view.

The relationship between the mean weights of the population samples, their protein intake and the calorie value of their diets

The maintenance of body-weight in adults depends upon the balance between calorie intake and energy expenditure, but the body-weight attained by an individual is infuenced by the calorie value of the diet and its protein content, provided the supply of other nutrients is adequate (Cannon, I948; Sherman, Pearson \& Bal, r950).

Hynes, Ishaq \& Verma (1946) and Verma, Dilwali \& Thomson (1947) recorded the increase in weight that followed the addition of animal protein to the diets of Indian Army recruits, whose diets had been previously vegetarian. These findings have been taken to add 'one more bit of evidence for the presence of the "elusive animal protein factor"' (Anonymous, 1948; Aitken, 1949), and further evidence suggests that this factor may be identical with vitamin $B_{12}$ (Anonymous, I949; Wetzel, Fargo, Smith \& Helikson, 1949).

The data here presented show that the greatest mean weights are attained by the populations that eat most animal protein. The Soragbemi fishermen have a mean weight of IIg $\mathrm{lb}$. in spite of a calorie intake lower than that of any other group. The mean weight of the grain-eating populations (Bida, Kontagora and Zuru farmers) is only $116 \mathrm{lb}$. despite intakes of calories, total protein and vitamins of the B-complex greater than those of the fishermen. The lowest mean weight was found in the Illu farmers, whose daily consumption of protein was only $43 \mathrm{~g}$. With plentiful amounts of mixed protein and calories the mean weight of the Warri traders was found to be $136 \mathrm{lb}$. These findings provide further evidence in favour of the existence of the 'animal 
protein factor'. It is necessary to point out, however, that the high calcium intake of the fishermen may be of importance in their development. Sherman \& Pearson (1947, 1948) showed that symptoms suggestive of calcium deficiency may appear when animal protein is added to a diet, if the calcium content of the diet is kept constant.

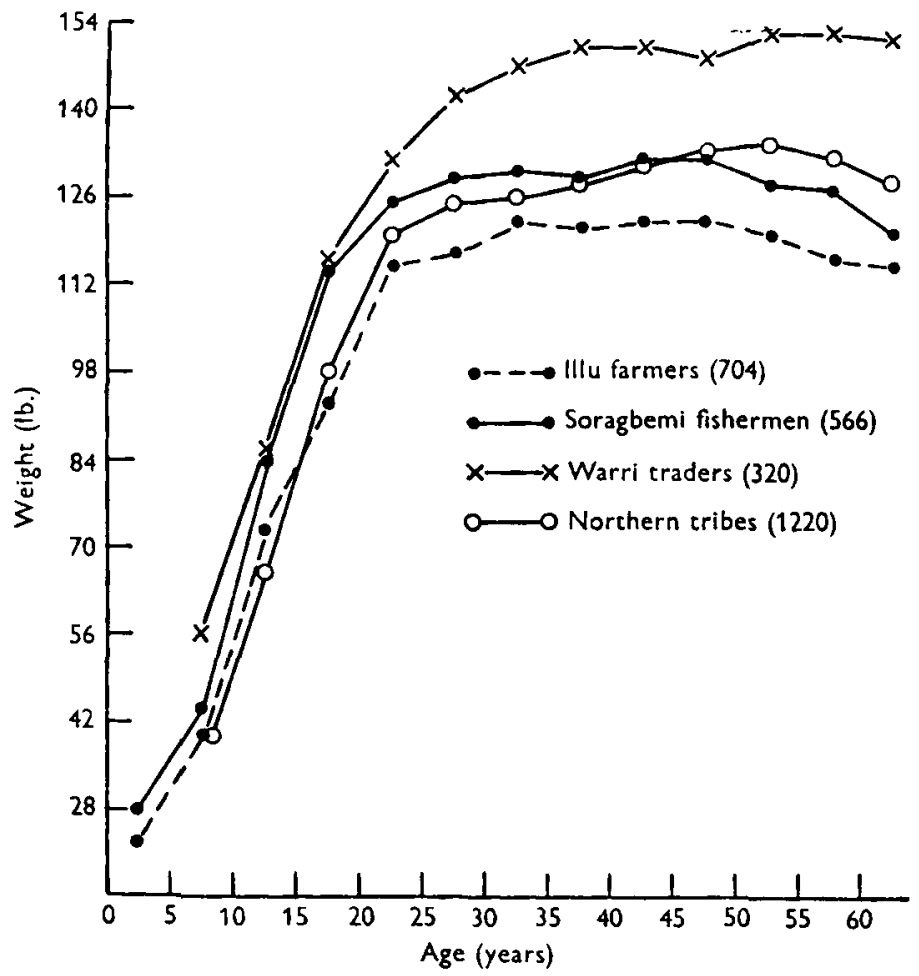

Fig. I. Mean weights in 5-year age groups of male Nigerian peasants and traders. Figures in parentheses indicate numbers studied.

It should be noted that the weights of the northern tribes are less than those of the Soragbemi fishermen until between 40 and 50 years of age (Figs. I and 2), and thereafter they exceed those of the fishermen: also, the falling-off in mean weight that occurs in all samples of the population in the older age groups is more marked in the Soragbemi fishermen and Illu farmers than in the northern tribes. These weight records, considered in conjunction with calorie values of the diets, are in accordance with the views of Clements (personal communication) that 'the fall-off in body-weight in the older age groups occurs in those populations where the calorie intake is below optimum'.

The fishermen have a lower intake of B-complex vitamins than the grain-eating tribes, and yet have better general development and suffer less from cirrhosis of the liver than any other group (Table 8). Drill \& Loomis (1948) showed that a high intake of animal protein can compensate to some extent for a chronic deficiency of B-complex vitamins in the prevention of functional and histological derangement of the liver. 
It appears to be possible that such a compensatory mechanism is responsible, not only for the low incidence of cirrhosis among the fishermen, but also for their good general development.

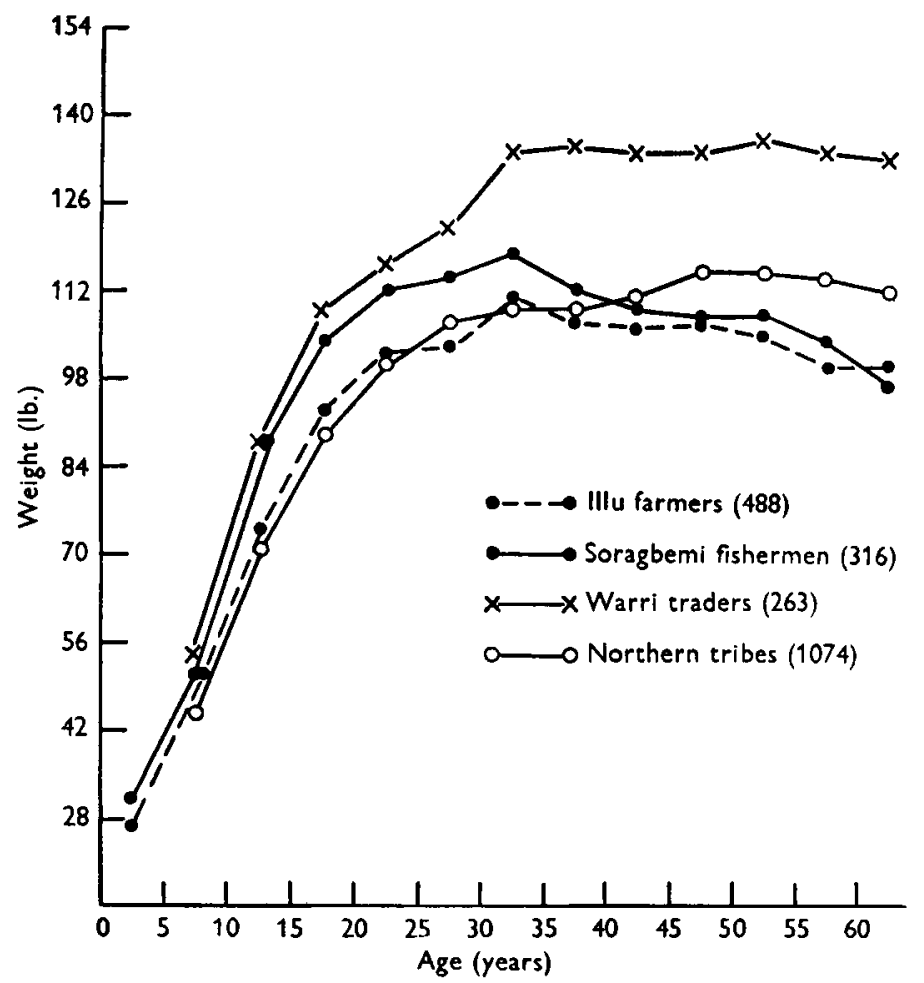

Fig. 2. Mean weights in 5-year age groups of female Nigerian peasants and traders. Figures in parentheses indicate numbers studied.

\section{SUMMARY}

I. An account is given of a nutritional survey carried out in Southern Nigeria in 1949 and 1950.

2. The methods employed to determine the nutrient intake and nutritional status of the population are described, and the findings are presented and compared with those of a previous investigation carried out in Northern Nigeria in 1947 and 1948 (Nicol, 1949).

3. The following conclusions are drawn regarding the effects of specific vitamin deficiencies:

(a) Vitamin A deficiency results in corneal opacity associated with dryness of the conjunctiva, staring hair and hypochromotrichia, general xerosis and follicular hyperkeratosis, 'elephant skin', 'crackled' skin and night-blindness.

(b) Riboflavin deficiency results in superficial corneal opacity unassociated with dryness of the conjunctiva, increased vascularity of the conjunctiva, angular stomatitis, nasolabial seborrhoea, and permanent gooseflesh. 
(c) Aneurin deficiency leads to symptoms such as diffuse neuralgic pains, dyspepsia, emotional instability and undue proneness to fatigue and to tenderness of the calves.

(d) Deficiency of nicotinic acid results in 'pebbling' of the filiform papillae of the tongue.

4. Folliculosis, atrophic skin and proliferative lesions of the conjunctiva were not attributed to any specific deficiency. Long-continued minor traumata are probably the most important causes of these lesions, but deficiency of B-complex vitamins, and of riboflavin in particular, may exaggerate the effects of trauma. Pigmentation of the sclera is not the result of nutritional deficiency.

5. Evidence suggests that lack of a factor present in animal protein, possibly tryptophan, in addition to deficiencies of riboflavin and nicotinic acid, is responsible for the lesions of the tongue so commonly found among undernourished tropical communities.

6. Data are presented from which it is deduced that $\mathrm{r} \cdot 37 \mathrm{mg}$ riboflavin (0.01 I $\mathrm{mg} / \mathrm{lb}$. body-weight; $0.46 \mathrm{mg} / 1000 \mathrm{Cal}$.) and $\mathrm{r} .02 \mathrm{mg}$ aneurin $(0.34 \mathrm{mg} / \mathrm{r} 000 \mathrm{Cal}$.$) are not$ sufficient as daily allowances to cover all the requirements of daily life and inherent individual variability.

7. Consideration of the mean weights and nutrient composition of the diets of samples of the Nigerian population was taken to supply evidence in favour of the existence of a growth-promoting 'animal protein factor'.

8. Certain other clinical features are discussed.

I am grateful to the Director of Medical Services, Nigeria, for permission to publish this paper, and to Dr A. P. Meiklejohn, of the Department of Medicine and Dr R. Passmore, of the Department of Social Medicine, University of Edinburgh, for advice, criticism and help.

I am indebted to Mr D. R. Rosevear, Deputy Chief Conservator of Forests, Nigeria, for help with the botanical and zoological classifications.

Mr John Bull, of the Warri Hospital staff, rendered valuable assistance.

\section{REFERENCES}

Abbott, P. H. (1950). Trans. R. Soc. trop. Med. Hyg. 43, 477.

Aitken, F. C. (1949). Brit. F. Nutrit. 3, 403 .

Anonymous (1948). Nutr. Rev. 6, 181.

Anonymous (1949). Nutr. Rev. 7, 136.

Anonymous (r950). Nutr. Rev. 8, 85.

British Medical Association (1950). Report of the Committee on Nutrition. London: British Medical Association.

Cannon, P. R. (1948). Protein and Amino Acid Deficiencies. American Lecture Series, no. 27. Springfield, Illinois: C. C. Thomas.

Chance, M. R. A. \& Dirnhuber, P. (1949). Parasitology, 39, 300.

Chatfield, C. (1949). F.A.O. Nutritional Studies, no. 3. Washington, D.C.: Food and Agriculture Organization of the United Nations.

Crandon, J. H., Lund, C. C. \& Dill, D. B. (1940). New Engl. F. Med. 223, 353.

Drill, V. A. \& Loomis, T. A. (1948). F. Nutrit. 35, 333.

Elsom, K. O., Lewy, F. H. \& Heublein, G. W. (1940). Amer. F. med. Sci. 200, 757.

Goldberger, J. \& Tanner, W. F. (I92I). Publ. Hlth Rep., Wash., 37, 462. 
Gyorgy, P. (1947). Conference on Liver Injury. Transactions of the Sixth Meeting, p. 67. New York: Josiah Macy Jr. Foundation.

Himsworth, H. P. \& Lindan, O. (1949). Nature, Lond., 163, 30.

Hume, E. M. \& Krebs, H. A. (r949). Spec. Rep. Ser. med. Res. Coun., Lond., no. 264.

Hynes, M., Ishaq, M. \& Verma, O. P. (1946). Indian f. med. Res. 34, 273.

Keys, A. (r949). Nutr. Abstr. Rev. 19, I.

Keys, A., Henschel, A., Taylor, H. L., Mickelsen, O. \& Brozek, J. (1945). Amer. F. Physiol. I44, 5.

Kodicek, E. (1948-9). Brit. F. Nutrit. 2, 373.

Marrack, J. R. (1948-9). Brit. F. Nutrit. 2, 147.

Mayer, J. \& Krehl, W. A. (1948). F. Nutrit. 35, 523.

McLester, J. S. (1949). Nutrition and Diet in Health and Disease, 5 th ed. London: W. B. Saunders Co.

Medical Research Council (1948). Lancet, 254, 853.

Melnick, D., Hochberg, M. \& Oser, B. L. (1945). F. Nutrit. 30, 67.

National Research Council (1948). Repr. nat. Res. Coun., Wash., no. I29.

Nicholls, L. (1945). Tropical Nutrition, and ed. London: Baillière, Tindall and Cox.

Nicol, B. M. (1949). Brit. F. Nutrit. 3, 25.

Passmore, R. (1948). Nutritional Diseases in India. Calcutta: U. N. Dhur and Sons Ltd.

Platt, B. S. (1945). Spec. Rep. Ser. med. Res. Coun., Lond., no. 253.

Platt, B. S. (1946). Trans. R. Soc. trop. Med. Hyg. 40, 379.

Sharman, I. M. (1949). Brit. F. Nutrit. 3, x.

Sherman, H. C. \& Pearson, C. S. (r947). Proc. nat. Acad. Sci., Wash., 33, 264.

Sherman, H. C. \& Pearson, C. S. (1948). Proc. nat. Acad. Sci., Wash., 34, 585.

Sherman, H. C., Pearson, C. S. \& Bal, M. E. (1950). Proc. nat. Acad. Sci., Wash., 36, 106.

Sinclair, H. M. (1948). Vitamins and Hormones, 6, 101.

Vedder, E. B. \& Rosenberg, C. (1938). F. Nutrit. 16, 57.

Verma, O. P., Dilwali, C. K. \& Thomson, A. M. (1947). Indian $¥$. med. Res. 35, 41.

Wetzel, N. C., Fargo, W. C., Smith, I. H. \& Helikson, J. (r949). Science, r ro, 65 I.

Williams, R. D., Mason, H. L. \& Smith, B. F. (1939). Proc. Mayo Clin. 14, 787.

Williams, R. D., Mason, H. L., Smith, B. F. \& Wilder, R. M. (1942). Arch. intern. Med. 69, 72 I.

Williams, R. D., Mason, H. L., Wilder, R. M. \& Smith, B. F. (1940). Arch. intern. Med. 66, 785. 